\title{
Hazard Identification and Risk Assessment in Water Treatment Plant considering Environmental Health and Safety Practice
}

\author{
Fajrul Falakh ${ }^{1 *}$, Onny Setiani ${ }^{2}$ \\ ${ }^{1}$ Master Program of Environmental Science, School of Postgraduate Studies, Diponegoro University, Semarang-Indonesia \\ ${ }^{2}$ Departement of Environmental Health, Faculty of Public Health, Diponegoro University, Semarang - Indonesia
}

\begin{abstract}
Water Treatment Plant (WTP) is an important infrastructure to ensure human health and the environment. In its development, aspects of environmental safety and health are of concern. This paper case study was conducted at the Water Treatment Plant Company in Semarang, Central Java, Indonesia. Hazard identification and risk assessment is one part of the occupational safety and health program at the risk management stage. The purpose of this study was to identify potential hazards using hazard identification methods and risk assessment methods. Risk assessment is done using criteria of severity and probability of accident. The results obtained from this risk assessment are 22 potential hazards present in the water purification process. Extreme categories that exist in the risk assessment are leakage of chlorine and industrial fires. Chlorine and fire leakage gets the highest value because its impact threatens many things, such as industrial disasters that could endanger human life and the environment. Control measures undertaken to avoid potential hazards are to apply the use of personal protective equipment, but management will also be better managed in accordance with hazard control hazards, occupational safety and health programs such as issuing work permits, emergency response training is required, Very useful in overcoming potential hazards that have been determined.
\end{abstract}

\section{Introduction}

Occupational safety and health is heavily influenced by occupational hazards identified and managed in a competent risk assessment process. Hazards in the workplace can be physical, chemical or psychological and can lead to workplace incidents and work-related injuries, which have an impact on organizational productivity and profitability. [1]

Hazard Identification Risk Assessment (HIRA) is a method for determining and providing hazards based on their probability, frequency and severity and evaluating adverse consequences, including potential loss and injury. The work process in the industry must pay attention to aspects of environmental health and safety in order to support the effectiveness of the industry. The industry must identify hazards, assess the associated risks to tolerate continuous levels, risk assessments have been made using risk guidelines and standards. [2][3]

Water Treatment Plant (WTP) is an important infrastructure to guarantee human and environment health. As water supply, they have a key role in giving healthy clean water access to the society. In the progress of this, environmental and health safety aspect becomes things to be concerned about. [4] The high hazard impacts in workplace often become the cause of work accident and occupational disease.

Working in the field of water treatment is considered dangerous, especially as it can lead to frequent deaths in confined spaces. Occupational safety and health is not particularly noticed in this area, many decision makers consider it to be somewhat less dangerous at the moment, but processing workers are still experiencing the possibility of health problems and deaths, especially exposure to chemicals as materials for water purification. [4][5].

Water treatment companies use machines and equipment that are likely to cause injury to workers. Accidents that occur can be caused by negligence of workers when operating machinery and equipment or unsafe working environment conditions. Potential hazards that often occur are defects in operation, exposure to chemicals and work fatigue.

The study was conducted using the HIRA (Hazard Identification and Risk Assessment) method to identify potential hazards found in the workplace. By identifying potential hazards and work risks, it is expected to facilitate the company in the management and control of safety in the workplace and minimize the possibility of accidents.

\section{Literature review}

Hazard Identification is a proactive process to identify hazards and eliminate or minimize/reduce the risk of injury/illness to workers and damage to property, equipment and the environment. It also allows us to show our commitment and due diligence to a healthy and 
safe workplace. We must identify hazards and potential hazards in the workplace in order to be able to take action to eliminate or control them. [8]

Table 1. Description of Likelihood Level

\begin{tabular}{|c|l|l|}
\hline Level & Likelihood & $\begin{array}{l}\text { Expected or actual frequency } \\
\text { experienced }\end{array}$ \\
\hline 1 & Rare & $\begin{array}{l}\text { May only occur in exceptional } \\
\text { circumstances; simple process; } \\
\text { no previous incidence of non- } \\
\text { compliance }\end{array}$ \\
\hline 2 & Unlikely & $\begin{array}{l}\text { Could occur at some } \\
\text { time; less than } 25 \% \\
\text { chance of occurring; non- } \\
\text { complex process \&/or } \\
\text { existence of checks and } \\
\text { balances }\end{array}$ \\
\hline 3 & Possible & $\begin{array}{l}\text { Might occur at some time; } 25- \\
50 \% \text { chance of occurring; } \\
\text { previous audits/reports indicate } \\
\text { non-compliance; complex } \\
\text { process with extensive checks } \\
\text { \& balances; impacting factors } \\
\text { outside control of organisation }\end{array}$ \\
\hline 4 & Likely & $\begin{array}{l}\text { Will probably occur in most } \\
\text { circumstances; } 50 \text {-75\% chance } \\
\text { of occurring; complex process } \\
\text { with some checks \& balances; } \\
\text { impacting factors outside } \\
\text { control of organisation }\end{array}$ \\
\hline 5 & Almost & $\begin{array}{l}\text { Can be expected to occur in } \\
\text { most circumstances; more than } \\
75 \% \text { chance of occurring; } \\
\text { complex process with minimal } \\
\text { checks \& balances; impacting } \\
\text { factors outside control of } \\
\text { organisation }\end{array}$ \\
\hline
\end{tabular}

This is a step by step process to guide responsible persons to an effective hazard identification, assessment and controls system. The steps include:

- Hazard Assessment: identifying the hazards and potential hazards, determining the risks and the risk designation (rating) associated to the hazard based on: Likelihood and severity

- Hazard control - controlling the hazards and the risks associated with the hazard

- Providing information, education, training and supervision on the hazards, risks and controls for employees affected by the hazards

- Review of the hazard assessment and control process

Table 2. Risk Assessment Matrix

\begin{tabular}{|l|l|l|l|l|l|l|}
\hline 5 & 5 & 10 & 15 & 20 & 25 \\
\cline { 2 - 7 } & 4 & 4 & 8 & 12 & 16 & 20 \\
\hline & 3 & 3 & 6 & 9 & 12 & 15 \\
\hline & 2 & 2 & 4 & 6 & 8 & 10 \\
\hline
\end{tabular}

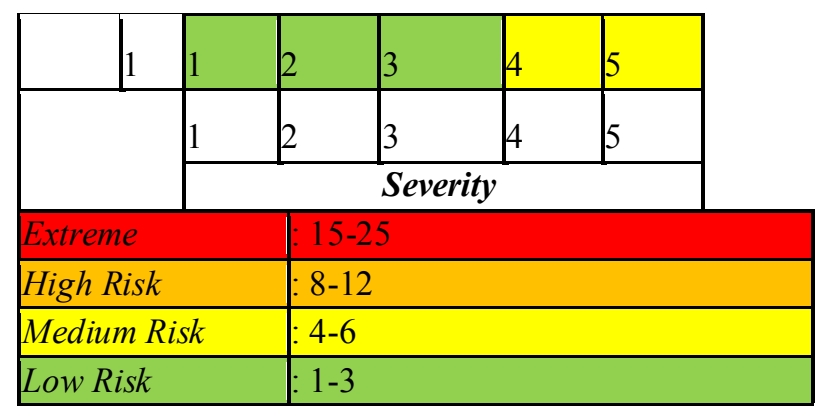

Table 3. Description of Severity Level

\begin{tabular}{|c|c|}
\hline Level & Description of Severity \\
\hline 1 & $\begin{array}{l}\text { - Minor onsite injuries (first aid and nondisabling, } \\
\text { reportable injuries). } \\
\text { - Property damage less than base level amount * } \\
\text { - Minor environmental impact (no remediation). } \\
\text { - Loss of production less than base level amount * } \\
\text { - No offsite impact or damage. No public concern or } \\
\text { media interest. }\end{array}$ \\
\hline 2 & $\begin{array}{l}\text { - Serious onsite injuries (temporary disabling worker } \\
\text { injuries). } \\
\text { - damage from } 1 \text { to } 20 \text { times base level. } \\
\text { - Moderate environmental impact (cleanup or } \\
\text { remediation in less than } 1 \text { week and no lasting impact } \\
\text { on food chain, terrestrial or aquatic life). } \\
\text { - Loss of production from } 1 \text { to } 20 \text { times base level } \\
\text { - Minor offsite impact (public nuisance-noise, } \\
\text { smoke, odor, traffic). } \\
\text { - Potential adverse public reaction. Some media } \\
\text { awareness. }\end{array}$ \\
\hline 3 & $\begin{array}{l}\text { - Permanent disabling onsite injuries or possible } \\
\text { fatality. } \\
\text { - Property damage from } 20 \text { to } 50 \text { times base level. } \\
\text { - Significant environmental impact (cleanup or } \\
\text { remediation less than } 1 \text { month and minor impact on } \\
\text { food chain, terrestrial or aquatic life). } \\
\text { - Loss of production from } 20 \text { to } 50 \text { times base level. } \\
\text { - Moderate offsite impact limited to property damage, } \\
\text { minor health effects to the public or first aid injuries. } \\
\text { - Adverse public reaction. Local media concern. }\end{array}$ \\
\hline 4 & $\begin{array}{l}\text { - Onsite fatality or less than four permanent disabling } \\
\text { worker injuries. } \\
\text { - Property damage from } 50 \text { to } 200 \text { times base level. } \\
\text { - Serious environmental impact (cleanup or } \\
\text { remediation requires } 3-6 \text { months and moderate } \\
\text { impact on food chain, terrestrial and/or aquatic life). } \\
\text { - Loss of production from } 50 \text { to } 200 \text { times base level. } \\
\text { - Significant offsite impact property damage, short- } \\
\text { term health effects to the public or temporary } \\
\text { disabling injuries. } \\
\text { - Significant public concern or reaction. National } \\
\text { media concern. }\end{array}$ \\
\hline 5 & $\begin{array}{l}\text { - Multiple onsite fatalities or four or more permanent } \\
\text { disabling onsite injuries. } \\
\text { - Property damage greater than } 200 \text { times base level. }\end{array}$ \\
\hline
\end{tabular}




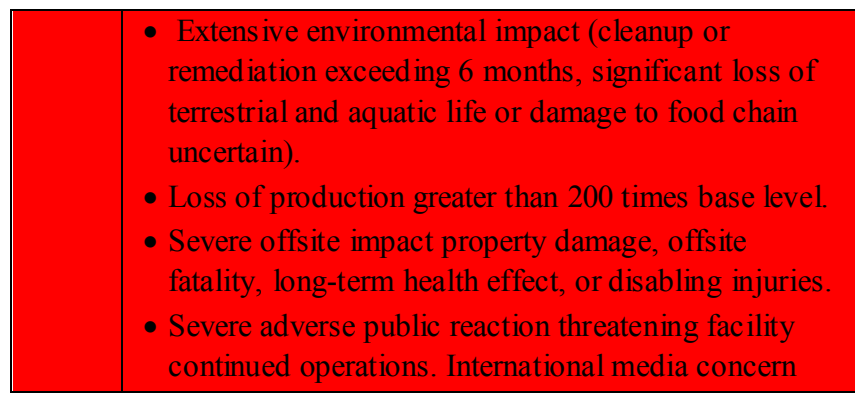

During the interview process, worker and safety officer is given a table containing the scale / category of likelihood and severity, so that the worker and the safety contractor can know and determine for themselves the category level of likelihood and severity. The value scale for likelihood is 1-5 ranging from an unlikely to almost certain level of probability.

While the value scale for severity is 1-5 ranging from insignificant to catastrophic severity. After the value of relative risk obtained then analyzed using Risk Assessment Matrix table. [7]

Risk is a measurement to analyze and evaluate the hazard. The measurement is made by identification on how severe and when likely of the hazard. In other words, the risk assessment is an in-depth look to specify situations, process and other harmful activities or hazard at workplace. [8]

Rating the hazard is one way to help determine which hazard is the most serious and thus which hazard to control first. Priority is usually established by taking into account the severity and Likelihood. By assigning a priority to the hazard, you are creating a rating or an action list.

The following factors play an important role:

- Severity of exposure - impact when exposed to the hazard.

- Likelihood - that an incident will occur when exposed to the hazard.

When the hazard is identified, determine the controls which are already in place to ensure this information is taken into account when assigning a risk designation.

Risk is presented in variety of ways to communicate the distribution of the risk throughout a plant and area in a workplace. The results of risk assessment that presented in a risk matrix are essential to make decision on risk control. Risk can be calculated using the following formula:

$$
\text { Risk (R) = Likelihood (L) x Severity (S). [7] }
$$

The phase of risk identification is essential, because it puts the bases of the risk analysis. Indeed, the data of risk identification will be the input of the evaluation, Therefore it is necessary to make an identification phase in an exhaustive way, to obtain the best results. [9]

\section{Methodologies}

The type and design of this research based on time research is cross sectional because the process of collecting data and observation of the variables done at once or at one particular time. While in terms of place, this research includes field research, because the research conducted and the way researchers in getting the data is directly plunged into the field by conducting interviews and observation

When viewed from the way of data collection, this study is observational because researchers obtain data through observations and interviews to workers and related parties in the company. In addition, the objects in this study were not treated during the course of the observational / observational study. Based on the nature of the problem and its data analysis, this research is included in descriptive research because this research does not make comparisons or connections between variables. This study describes a situation objectively.

Variables to be studied in this research are hazard identification, risk assessment, and risk level determination on water installation process. The data collected in this study there are two types of primary data and secondary data. Primary data obtained through observation and interview. These observations and interviews are used to determine the potential water hazard clearance process, the magnitude of occupational risks and the working environment.

While the secondary data collected is a general description of the company, the work procedure, the number of workers, tools and hazardous materials in the water treatment process and accident control efforts that have been done.

Processing techniques and data analysis conducted based on observation and interview data. Based on the results of observation and interviews are known potential hazard and value. Identification of potential risk hazards in the water treatment plant will be very effective if done on the basis of the factual conditions of the workplace and existing work processes, this is an effort that can be done so that industrial health and environmental health programs can be done well in accordance with policies and Regulations that have been set.

\section{Result}

Risk Assessment is performed using the Risk Matrix as described in the literature study, the results obtained from this risk assessment are the 22 potential hazards present in the water purification process, these findings are based on assessments of workshops and processing units at subsequent water treatment plants Described in detail in table 4. According the existing categories of extreme risk, high risk, medium risk and low risk then the findings are grouped into each risk category.

Extreme categories that exist in the risk assessment are chlorine leak and industrial fires. Leakage of chlorine and fires get the highest value because their impact threatens many things, such as industrial disasters that can harm human life and the environment.

Hazards Chlorine can be absorbed through the skin and cause burns ranging from mild to severe depending on the length of the contact In addition chlorine can also be absorbed through the eye, causing burning or discomfort, irregular blinking, unconscious closure of 
eyelids, redness, and tearing. Large amounts of chlorine in the air can cause severe burns, pain, and blurred eyesight.

Therefore workers in storage must conduct a wellscheduled inspection so that the presence of chlorine can be safely maintained, besides that it is also necessary to have an emergency management control system that refers to leakage of chlorine and industrial fires, Prevention efforts from known potential hazards.

Table. 4 Hazard Identification Risk Assessment in Water Treatment Plant

\begin{tabular}{|c|c|c|c|c|c|c|c|}
\hline \multirow{2}{*}{ No } & \multirow{2}{*}{$\begin{array}{l}\text { Workshop or } \\
\text { Treatment unit }\end{array}$} & \multirow{2}{*}{$\begin{array}{l}\text { Hazard / Hazardous } \\
\text { Situation }\end{array}$} & \multirow{2}{*}{ Potential Risk } & \multirow{2}{*}{ Consequence } & \multicolumn{3}{|c|}{$\begin{array}{c}\text { Risk Assessment } \\
\text { Matrix }\end{array}$} \\
\hline & & & & & $\mathbf{L}$ & $\mathbf{S}$ & Risk Value \\
\hline 1 & $\begin{array}{l}\text { Flow Meter } \\
\text { Chamber }\end{array}$ & $\begin{array}{l}\text { Possible entrance and } \\
\text { entering the flow meter } \\
\text { chamber }\end{array}$ & $\begin{array}{l}\text { Chlorine inhalation } \\
\text { by operator working } \\
\text { inside the chamber }\end{array}$ & $\begin{array}{l}\text { Lost-time accident } \\
\text { up to fatality due to } \\
\text { chlorine inhalation }\end{array}$ & 3 & 2 & $\begin{array}{c}6 \\
\text { (medium Risk) }\end{array}$ \\
\hline 2 & $\begin{array}{l}\text { Demolition in } \\
\text { Chemical } \\
\text { Building }\end{array}$ & $\begin{array}{l}\text { Work at height }(8 \mathrm{~m}) \text { for } \\
\text { demolishing walls and } \\
\text { floors }\end{array}$ & $\begin{array}{c}\text { Falling from a } \\
\text { height of } \\
\text { approximate } 8 \\
\text { meter to the ground }\end{array}$ & $\begin{array}{l}\text { Permanent injury up } \\
\text { to fatality }\end{array}$ & 2 & 4 & $\begin{array}{c}8 \\
\text { (High Risk) }\end{array}$ \\
\hline 3 & Control Room & Electrical Hazard & Electric short circuit & $\begin{array}{c}\text { fractures, Fatality, } \\
\text { Disaster } \\
\end{array}$ & 3 & 5 & $\begin{array}{c}15 \\
\text { (Extreme Risk) } \\
\end{array}$ \\
\hline 4 & $\begin{array}{l}\text { Process of } \\
\text { Treatment }\end{array}$ & $\begin{array}{l}\text { Cleaning accumulation } \\
\text { sludge in channel raw water } \\
\text { inlet of accerator } 1,2 \text { at } \\
\text { once a month }\end{array}$ & $\begin{array}{c}\text { harmful } \\
\text { atmosphere, } \\
\text { difficulty of } \\
\text { entry/exit access }\end{array}$ & $\begin{array}{l}\text { Fatality accident } \\
\text { more than } 1 \text { person }\end{array}$ & 2 & 5 & $\begin{array}{c}10 \\
\text { (High Risk) }\end{array}$ \\
\hline 5 & $\begin{array}{l}\text { Process of } \\
\text { treatment }\end{array}$ & $\begin{array}{l}\text { Cleaning once a month } \\
\text { sludge extraction }\end{array}$ & $\begin{array}{l}\text { All confined space } \\
\text { risks, including fall, } \\
\text { electrical shock }\end{array}$ & Fatality accident & 2 & 4 & $\begin{array}{c}8 \\
\text { (High Risk) }\end{array}$ \\
\hline 6 & $\begin{array}{l}\text { Process of } \\
\text { treatment }\end{array}$ & $\begin{array}{l}\text { Working at height for } \\
\text { routine operating main } \\
\text { drain valve, noise, smell }\end{array}$ & Falling, slippery & Fatality accident & 1 & 4 & $\begin{array}{c}4 \\
\text { (Medium Risk) }\end{array}$ \\
\hline 7 & $\begin{array}{l}\text { Process of } \\
\text { treatment }\end{array}$ & $\begin{array}{l}\text { Working/cleaning over } \\
\text { compartment }\end{array}$ & Falling, drowning & Fatality accident & 1 & 4 & $\begin{array}{c}4 \\
\text { (Medium Risk) }\end{array}$ \\
\hline 8 & $\begin{array}{l}\text { Water treatment } \\
\text { line }\end{array}$ & $\begin{array}{l}\text { Working at height around } \\
\text { sand filter }\end{array}$ & Drowning, Falling & $\begin{array}{l}\text { Concussion, } \\
\text { fracture }\end{array}$ & 3 & 2 & $\begin{array}{c}6 \\
\text { (Medium Risk) } \\
\end{array}$ \\
\hline 9 & $\begin{array}{l}\text { Backwash pump } \\
\text { room }\end{array}$ & $\begin{array}{c}\text { Rotating part, noise, } \\
\text { slippery at backwash pump }\end{array}$ & $\begin{array}{c}\text { Injury at arm or } \\
\text { hand in Projection } \\
\text { of loose bolt, noise, } \\
\text { fall }\end{array}$ & $\begin{array}{l}\text { Arm amputation, } \\
\text { fracture, hearing } \\
\text { disorders, } \\
\text { concussion }\end{array}$ & 3 & 3 & $\begin{array}{c}9 \\
\text { (High Risk) }\end{array}$ \\
\hline 10 & $\begin{array}{l}\text { Gear box of } \\
\text { the turbine }\end{array}$ & Exposed rotating parts & $\begin{array}{l}\text { Injury at arm or } \\
\text { hand in Projection } \\
\text { of loose bolt }\end{array}$ & $\begin{array}{l}\text { Arm amputation, } \\
\text { shut down machine, } \\
\text { fracture } \\
\end{array}$ & 2 & 3 & $\begin{array}{c}6 \\
\text { (Medium Risk) }\end{array}$ \\
\hline 11 & $\begin{array}{l}\text { Chlorine } \\
\text { Facilities }\end{array}$ & Crash inside the site & $\begin{array}{l}\text { Personnel crashed } \\
\text { by chlorine vehicle }\end{array}$ & Fatality accident & 3 & 4 & $\begin{array}{c}12 \\
\text { (High Risk) }\end{array}$ \\
\hline 12 & $\begin{array}{l}\text { Chlorine } \\
\text { Facilities }\end{array}$ & Chlorine Leakage & $\begin{array}{l}\text { Inhalation of } \\
\text { chlorine gas }\end{array}$ & $\begin{array}{l}\text { Fatality accident, } \\
\text { Disaster } \\
\end{array}$ & 3 & 5 & $\begin{array}{c}12 \\
\text { (Extreme Risk) }\end{array}$ \\
\hline 13 & $\begin{array}{l}\text { Chlorine } \\
\text { Facilities }\end{array}$ & $\begin{array}{l}\text { Falling container when } \\
\text { loading/unloading }\end{array}$ & $\begin{array}{l}\text { Impacted by falling } \\
\text { heavy objects } \\
\text { (weight: }+1.8 \text { ton, } \\
\text { height: } 1.5 \mathrm{~m} \text { ) }\end{array}$ & $\begin{array}{c}\text { Fracture/irreversible } \\
\text { harm }\end{array}$ & 2 & 2 & $\begin{array}{c}4 \\
\text { (Medium Risk) }\end{array}$ \\
\hline 14 & Purchasing & $\begin{array}{l}\text { Wrong/miss } \\
\text { specification when } \\
\text { purchased devices, } \\
\text { equipments, tools or } \\
\text { materials and services }\end{array}$ & $\begin{array}{l}\text { Use of improper } \\
\text { devices, } \\
\text { equipments, tools, } \\
\text { materials }\end{array}$ & $\begin{array}{l}\text { Stop production, } \\
\text { fatality }\end{array}$ & 5 & 1 & $\begin{array}{c}5 \\
\text { (Medium Risk) }\end{array}$ \\
\hline 15 & Filter gallery & Working at height & $\begin{array}{c}\text { Falling at a height } \\
(6 \mathrm{M})\end{array}$ & Fatality accident & 2 & 4 & $\begin{array}{c}8 \\
\text { (High Risk) }\end{array}$ \\
\hline
\end{tabular}




\begin{tabular}{|c|c|c|c|c|c|c|c|}
\hline 16 & Laboratory & $\begin{array}{c}\text { Exposure to UV } \\
\text { radiation (The device has } \\
\text { a UV germicidal lamp } \\
\text { with a wavelength of } \\
257.7 \mathrm{~nm} \text {, including UV- } \\
\text { C type) }\end{array}$ & $\begin{array}{l}\text { Erythema (damage / } \\
\text { disorder) on the skin } \\
\text { and damage the } \\
\text { cornea of the eye }\end{array}$ & $\begin{array}{c}\text { Skin disorders or } \\
\text { skin and cataracts in } \\
\text { the eyes for the long } \\
\text { term }\end{array}$ & 4 & 2 & $\begin{array}{c}8 \\
\text { (High Risk) }\end{array}$ \\
\hline 17 & Reservoir & Confined space hazard & $\begin{array}{c}\text { Inadequate } \mathrm{O} 2 \\
\text { content, high toxic } \\
\text { gas content, leakage } \\
\text { current on electrical }\end{array}$ & $\begin{array}{l}\text { Fainting, poisoning, } \\
\text { death }\end{array}$ & 2 & 4 & $\begin{array}{c}8 \\
\text { (High Risk) }\end{array}$ \\
\hline 18 & Acid material & $\begin{array}{c}\text { Strong acid vapor in the } \\
\text { laboratory }\end{array}$ & $\begin{array}{c}\text { Inhalation, skin } \\
\text { contact }\end{array}$ & $\begin{array}{c}\text { Respiratory } \\
\text { disorders, Skin } \\
\text { sores } \\
\end{array}$ & 3 & 1 & $\begin{array}{c}3 \\
\text { (Low Risk) }\end{array}$ \\
\hline 19 & $\begin{array}{c}\text { Storrage \& } \\
\text { dosing system } \\
\text { H2SO4 }\end{array}$ & Exposure to $\mathrm{H} 2 \mathrm{SO} 4$ & $\begin{array}{c}\text { Steam H2SO4 } \\
\text { strong acid } \\
\text { operation of } \mathrm{H} 2 \mathrm{SO} 4 \\
\text { dosing pump for } \\
\text { water neutralization }\end{array}$ & $\begin{array}{l}\text { Blind, burns, } \\
\text { irritation }\end{array}$ & 2 & 4 & $\begin{array}{c}8 \\
\text { (High Risk) }\end{array}$ \\
\hline 20 & $\begin{array}{l}\text { Submersible } \\
\text { Pump }\end{array}$ & Electrical & $\begin{array}{l}\text { Electric caution, } \\
\text { Fire }\end{array}$ & Disaster, Injury & 1 & 5 & $\begin{array}{c}5 \\
\text { (Medium Risk) }\end{array}$ \\
\hline 21 & $\begin{array}{c}\text { Storage of } \\
\text { hazardous } \\
\text { chemical waste }\end{array}$ & Waste spills & $\begin{array}{l}\text { Hazardous chemical } \\
\text { waste spills at the } \\
\text { time of pouring, the } \\
\text { occurrence of waste } \\
\text { leakage }\end{array}$ & $\begin{array}{l}\text { Environmental } \\
\text { pollution, } \\
\text { poisoning, fainting }\end{array}$ & 3 & 2 & $\begin{array}{c}6 \\
\text { (Medium Risk) }\end{array}$ \\
\hline 22 & $\begin{array}{l}\text { Storage Poly } \\
\text { Aluminum } \\
\text { Chloride }\end{array}$ & Poly Aluminum Chloride & $\begin{array}{c}\text { Leaks on pipe } \\
\text { connections and ball } \\
\text { valves }\end{array}$ & $\begin{array}{l}\text { Irritation, impaired } \\
\text { vision, indigestion }\end{array}$ & 3 & 2 & $\begin{array}{c}6 \\
\text { (Medium Risk) }\end{array}$ \\
\hline
\end{tabular}

\section{Recapitulation of the risk value}

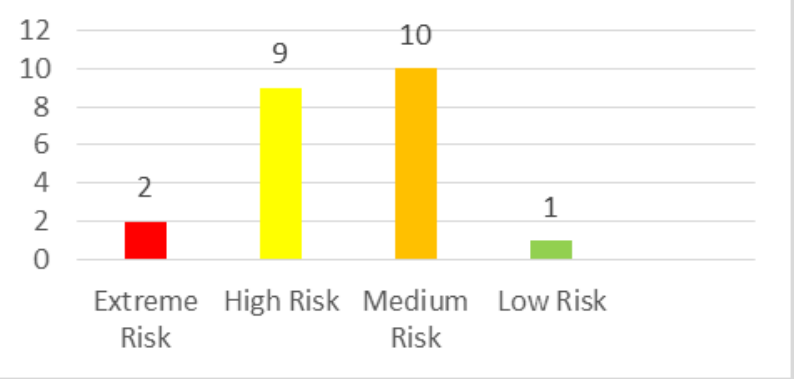

Fig 1. Recapitulation of the risk value

\section{Conclusion}

Potential occupational hazards in the water treatment industry are exposed to chemicals to workers, the potential danger of leaking chlorine gas can also greatly affect the safety and health of the industrial environment. Control measures undertaken to avoid potential hazards are to apply the use of personal protective equipment, but management will also be better managed in accordance with hazard control hazards, occupational safety and health programs such as issuing work permits, emergency response training is required, Very useful in overcoming potential hazards that have been determined.

\section{References}

1. S. T. Bahn, (pp. 1-9). Gold Coast, Queensland. Griffith University. (2012)

2. Islam, Tanveer; Ryan, Jeffrey R. ButterworthHeinemann is an imprint of Elsevier (2016)

3. R. Ramesh, M. Prabu, S. Magibalan, P. Senthilkumar, International Journal of ChemTech Research. (2017)

4. N. J. Brown, Ithaca, NY: Cornell University, Chemical Hazard Information Program. (2016)

5. A. Vantarakis, S. Paparrodopoulos, P. Kokkinos, G. Vantarakis, K. Fragou, and I. Detorakis. Journal of Environmental and Public Health Volume 2016 Article ID 8467023 (2016)

6. AY. Ambarani, The Indonesian Journal of Occupational Safety and Health (2017)

7. S. Ruchi, P. Praveen, International Journal of Engineering Research \& Technology. Vol 3 e-ISSN: 2278-0181 (2014)

8. Capital Health. Hazard Assessment Control Form. www.cdha.nshealth.ca/.../hazard-assessment-program (Accesssed 2 July 2017)

9. European Agency for Safety and Health at Work, Safety and health at work is everyone's concern, Numberg, Germany, (2007).

10. SJ. Moja, CS. Van Zuydam, Mphephu. J Geogr Nat Disast S6: 006 (2016) 